\title{
Upper trophic level predators indicate interannual negative and positive anomalies in the California Current food web
}

\author{
D. G. Ainley ${ }^{1}$, W. J. Sydeman ${ }^{1}$, J. Norton ${ }^{2}$ \\ ${ }^{1}$ PRBO International Biological Research, 4990 Shoreline Highway, Stinson Beach, California 94970, USA \\ ${ }^{2}$ Southwest Fisheries Science Center-PFEG, National Marine Fisheries Service (NOAA), PO Box 831, Monterey, \\ California 93942, USA
}

\begin{abstract}
We used a 21 yr time series of productivity for 6 seabird species nesting in large numbers at the Farallon Islands, $40 \mathrm{~km}$ offshore of San Francisco, California, USA, to assess proximate and remote factors leading to variation in the food supplies available to these predators. The latter sampled prey throughout a $3200 \mathrm{~km}^{2}$ area. Depending on foraging ecology and reproductive capacity, some species were more sensitive to food web perturbation than others. A serious lack of food was indicated by negative reproductive anomalies during all warm-water events, some of which were classified as tropical El Niño and others which were not. Equally spectacular but positive anomalies occurred during years adjacent to the negative ones, particularly evident among the most sensitive species. Much of the annual variation, positive or negative, in seabird reproductive success was explained by variation in the Southern Oscillation and/or the Aleutian low pressure system, both of which affect sea-surface temperature and thermocline depth off California. Results indicate that perturbations in the marine food web of the California eastern boundary current system, as indicated by the availability of food to seabirds, are much more complex than is generally appreciated, and are not confined only to negative excursions from normalcy. ENSO is important, but other global atmosphere-ocean phenomena affect the California Current just as dramatically.
\end{abstract}

KEY WORDS: California Current - El Niño $\cdot$ Food web - Interannual variability - La Niña $\cdot$ Seabirds Aleutian low pressure system

\section{INTRODUCTION}

The intense 1982-83 El Niño, i.e. the warm phase of the El Niño-Southern Oscillation (ENSO) cycle, dramatically increased awareness of the global interaction between the atmosphere and ocean and subsequent effects on marine biological processes (Barber \& Chavez 1984, 1986, Norton et al. 1985, Robinson \& del Piño 1985, Pearcy \& Schoener 1987). Such an interaction had been known for some time (e.g. Glantz \& Thompson 1981), but then additional study or analysis of old data began at levels unprecedented in this area of research. Certainly, the advance of computers, which allowed much greater access to global data sets, and integration of such sets led to success of the renewed analysis.
Particularly exciting to marine vertebrate ecologists have been the longer-term data sets that link top trophic-level predators to oceanographic events that affect food webs and change the availability of prey (e.g. Boersma 1978, Murphy 1981, Paulik 1981, Duffy et al. 1984, Shannon et al. 1984, Norton 1987). These linkages are also evident in the 16 yr time series compiled on prey availability and the breeding ecology of 6 species in the seabird community at the Farallon Islands, California, USA, 1971 to 1986 (Ainley \& Boekelheide 1990). These islands lie within the central upwelling zone of the California Current system (Parrish et al. 1981), which, as with other eastern boundary currents, is among the most oceanographically variable areas of the world ocean at all spatial and temporal scales (Glantz \& Thompson 1981). 
Ainley \& Boekelheide (1990) indexed relative prey availability by relating Farallon seabird diet to breeding productivity (mean number of young raised per breeding pair), which measures the success of parents in simultaneously feeding themselves and their chicks, an energetically demanding activity. In concert, Ainley et al. (1993) showed that the prevalence of important prey species in seabird diet (i.e. percent composition) was almost exactly correlated with prevalence of these prey in extensive mid-water trawl surveys designed to capture small fish (of suitable size for bird consumption) throughout the upper water column of the $3200 \mathrm{~km}^{2}$ foraging range of the birds. Moreover, absolute prevalence in surrounding waters of the single most important prey, juvenile rockfish Sebastes spp., was indicated equally by both the Farallon seabird diet and the trawls. Such a strong connection between reproductive success and prey availability is not novel to the Farallon system, however, but has been shown in a number of systems and studies as summarized elegantly by Montevecchi (1993).

Thus, the extreme variability in diet and reproductive success of the Farallon seabirds can provide insights into the proximate and remote causes of foodweb variation. The seabirds sample intensively year after year in a way that would be financially prohibitive using the classical methods of fisheries oceanography. Seabird reproductive anomalies, as we measured them, are independent of population size and structure as shown indirectly by Ainley \& Boekelheide (1990). Proximate causes of the anomalies are mediated through availability of their primary prey: euphausiids, small fish and cephalopods (Ainley \& Boekelheide 1990, Sydeman et al. 1991, and 'Results' herein). Various analyses have shown significant correlations between diet or reproductive success and local sea level, sea-surface temperature and the strength of upwelling during the late winter months (January to March) preceding the bird nesting season (Ainley \& Boekelheide 1990, Ainley et al. 1993, Nur et al. 1993). These factors are also known to correlate with regional abundance of microzooplankton (Bernal 1981, Chelton 1981, McLain \& Thomas 1983), which are the prey of small fish. Ultimately, the critical factors are likely the local levels of primary production and, more importantly, the efficiency by which it is assimilated into the upper trophic levels (e.g. Peterman \& Bradford 1987).

An analysis by Norton \& McLain (1994; see also Norton et al. 1994) provides the basis for exploring the more remote factors that affect local ocean conditions and ultimately the food web of coastal central California. Using time-series analysis, these authors found significant correlation between water temperatures in the upper $300 \mathrm{~m}$ of the water column off California and 2 ocean-atmosphere systems: atmospheric pressure in
Darwin, Australia, as part of the Southern Oscillation (SO), and pressure at $45^{\circ} \mathrm{N}, 165^{\circ} \mathrm{W}$, as part of the Aleutian low (hereafter called the Aleutian low pressure system index, or AL), 1954 to 1986 . The warming effect of variation in the AL (Empirical Orthogonal Function 2, or EOF2, of Norton \& McLain 1994) was confined to the upper $100 \mathrm{~m}$, in contrast to the deeper warming driven by SO (EOF1). SO leads to warmer waters by a perturbation of the deep thermal structure through coastally trapped Kelvin waves, but AL leads to warmer water by a relaxation or change of prevailing winds that allows the normally warmer waters offshore of the California Current to flow toward the coast. The latter flow, in turn, promotes additional warming because the atmospheric pressure gradient becomes more conducive to northward geostrophic advection. The response of the ocean off California to variation in the $\mathrm{AL}$ is almost immediate, i.e. a 0 -order response, relative to the lagged effects of SO.

Norton \& McLain (1994) further partitioned the timeseries results into 2 seasonal components: the springsummer ( $\mathrm{S}$ ) warming period (March to August; to be designated, for example, as EOF1S or SO-Summer and EOF2S or AL-Summer) - hereafter denoting the period at the start of the designated year - and the fall-winter (W) cooling period (September to February, EOF1W or SO-Winter and EOF2W or AL-Winter). Data were averaged from 6 coastal blocks in the eastern North Pacific between the latitudes of Vancouver, British Columbia, Canada, and San Diego, California (33 to $50^{\circ} \mathrm{N}$ ). In actuality, the 2 time periods represent 12 mo intervals, e.g. one spring-summer to the next spring-summer, over which ocean-atmosphere processes were integrated (in both the ecological and analytical senses) to affect the measured (i.e. 'differenced') state of the nominal period relative to the previous respective period. The mid-point of the spring-summer 12 mo interval would be January and that of the fallwinter 12 mo interval would be June.

Our objectives in this paper, using a longer seabird data set from the Farallones than that published by Ainley \& Boekelheide (1990) plus the results of Norton \& McLain (1994), were to jdentify (1) the relative degree to which the SO and AL affect variation in the availability of prey to seabirds in the coastal central California food web (as indicated by seabird reproductive success) and (2) the relative degree to which the 2 remote factors explained variation better than local factors, such as sea-surface temperature.

\section{SPECIES STUDIED, DATA AND METHODS}

We collected seabird productivity data annually at the Farallon Islands $\left(37.6^{\circ} \mathrm{N}, 137.0^{\circ} \mathrm{W}\right), 40 \mathrm{~km}$ off- 
shore of San Francisco, California. Methods and most of the productivity data set (1971 to 1986) are presented and discussed in Ainley \& Boekelheide (1990); data collected in the same way from 1987 to 1991 are presented herein for the first time.

The 6 seabird species investigated in detail are the 'sampling devices' by which we assessed food web variation. Included were Brandt's and pelagic cormorants Phalacrocorax penicillatus and $P$. pelagicus; western gull Larus occidentalis; common murre Uria aalge; pigeon guillemot Cepphus columba; and Cassin's auklet Ptychoramphus aleuticus. For most species, respective Farallon numbers comprised a significant proportion of California and West Coast populations (Ainley \& Boekelheide 1990). These species together sample all of the water column over the continental shelf and much of it over the slope. The cormorants and the murre feed to depths near $100 \mathrm{~m}$, the guillemot feeds to slightly shallower depths, the auklet to $35 \mathrm{~m}$ and the gull at the surface. The Brandt's cormorant, gull and murre forage within $80 \mathrm{~km}$ of the Farallones, the auklet within $30 \mathrm{~km}$ and the others within $<5 \mathrm{~km}$. The auklet is exclusively a planktivore (mainly euphausiids); the Brandt's cormorant and to a lesser extent the guillemot are piscivores. The remainder feed on fish, cephalopods and macrozooplankton the murre is more a planktivore than the others in this subgroup). The gull is the most catholic of all, being both a scavenger and a predator on anything edible. The sampling (= nesting season) of the auklet extends from March to July and that of the other species from late April to August, with some interspecific and much annual variation as a function of feeding and breeding capabilities (Ainley \& Boekelheide 1990). The murre and auklet lay but one egg per breeding attempt and, thus, show lower annual variability in reproductive success than the other species (Ainley \& Boekelheide 1990; see 'Results').

In this exploratory analysis, we used stepwise regression, starting with a full model (i.e. all factors) to determine atmospheric-oceanographic factors that affected reproductive success of each species (chicks fledged per pair that attempted breeding, i.e. laid at least $1 \mathrm{egg}$ ). We were not testing hypotheses at this stage, but using the statistics described by Seber (1977, p. 362-378), we sought relationships to explain variability by finding the 'best' regression (maximum adjusted $r^{2}$ ). Thus, we sought the factors that maximized the explained variation in seabird reproductive success and, therefore, some of the factors retained in the models had p-values slightly $>0.05$. We present all $p$-values and significance levels for readers only interested in those factors significant at $p<0.05$

Numerous studies show that ENSO affects the local variables we used, as it also does variation in the
Aleutian Low (Norton \& McLain 1994); thus, none of the variables were 'independent', which is true for any study attempting to relate aspects of ocean weather and climate. Our point was to determine whether the more remote vs the local variables alone, e.g. ENSO vs variation in the Aleutian Low vs local upwelling, when each variable was held constant in the regressions, could better explain variation in reproductive success. Variables that contributed nothing were dropped from the model. Among variables, we included the springsummer (S) and fall-winter (W) EOF1 (SO) and EOF2 (AL) of Norton \& McLain (1994), as well as data series of local ocean factors that have been shown to affect the seabird food web of central California: (a) Bakun's (1973) Upwelling Index during January and February, combined, for $36^{\circ} \mathrm{N}$ off California (Ainley et al. 1993); (b) average daily sea-surface temperature at the Farallones during March (Nur et al. 1993); and (c) average daily sea level at San Francisco during February (Chelton et al. 1982, McLain et al. 1985).

Data sets of local variables were compiled by the National Oceanic and Atmospheric Administration (see 'Acknowledgements'), except for the temperatures, which were collected daily at the Farallones (Ainley \& Boekelheide 1990, PRBO unpubl. data). The regression analyses using physical conditions included the years 1971 to 1986 , the period of overlap between data on reproductive success and the data from Norton $\&$ McLain (1994). In the tables, the local variables are referred to as follows: UW-J+F = upwelling index January \& February combined, T-MAR = average daily sea-surface temperature at the Farallones during March, SL-FEB = average daily sea level at San Francisco during February. EOF1 is designated as $\mathrm{SO}$ and EOF2 as AL (e.g. EOF1S = SO-Summer).

Using rockfish data from Ainley et al. (1993) we also correlated rockfish prevalence to the above physical factors in the models. A suitable index to rockfish availability is the proportion of rockfish in the diet fed to chicks by the common murre; this index is closely comparable to results of systematic trawling by the National Marine Fisheries Service in central California (Ainley et al. 1993). Allowed by temporal overlap, we used the seabird productivity time series, 1973 to 1991, to relate reproductive success to diet variability (no diet data available for 1971 and 1972), and that of 1973 to 1986 to relate diet variability to the Norton \& McLain (1994) data set (no physical time series available after 1986).

We used $\log (1+\mathrm{rs})$, where rs is reproductive success, to meet criteria of normality in the reproductive success data for pigeon guillemots and pelagic cormorants (both species exhibited many years when success was zero). These transformations also provided highest r-values. Alternating patterns of high and low reproductive success were investigated using the autocorre- 
lation between adjacent years (Priestly 1981) and a non-parametric Runs Test (Siegel 1956). Statistical significance in the latter 2 tests was considered at $p \leq 0.05$ (see Siegel 1956). However, considering the relative shortness of the reproductive time series, the fact that the Runs Test is a 2-tailed test and that this is an exploratory analysis, we believe that a value of $p=0.10$ is worth our attention.

\section{RESULTS}

\section{Variability in seabird productivity}

The seabirds, and especially those species that can lay multiple-egg clutches, exhibited significantly reduced productivity or total reproductive failure during 1973 ,

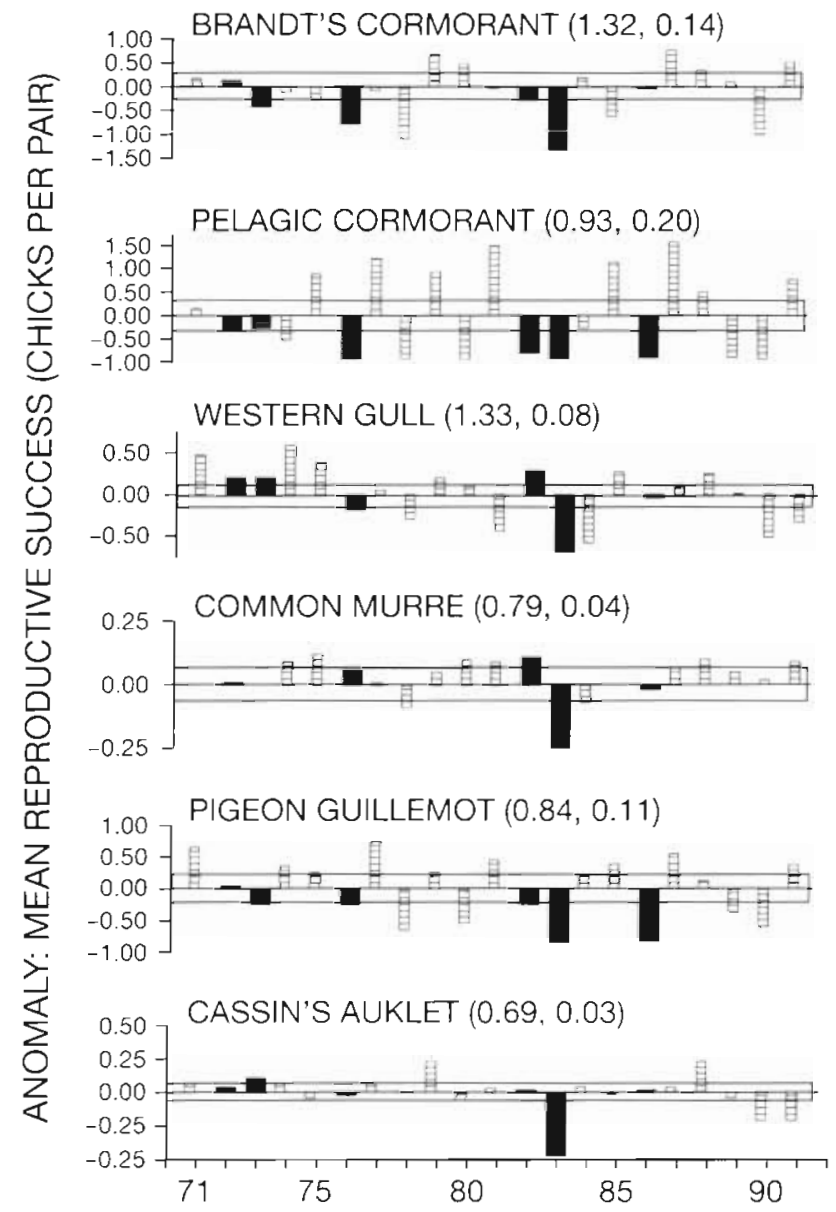

Fig. 1 Divergence of values for reproductive success expressed as anomalies from the mean for 6 species of seabirds nesting on the Farallon Islands, 1971 to 1991. Lines above and below mean lines indicate the $95 \%$ confidence intervals of mean reproductive success (not mean anomaly); dark bars indicate ENSO years; mean reproductive success land standard error) in parentheses

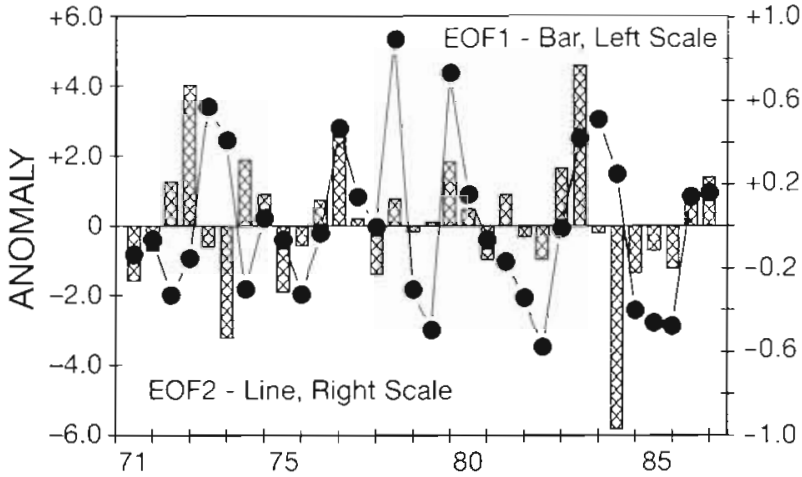

Fig. 2. Values of Empirical Orthogonal Functions from Norton \& McLain (1994) for the years 1971 to 1986. Each year is divided into 2 periods: spring-summer (March to August) and fall-winter (September to February of following year). Bars: EOF1 (Southern Oscillation); -- EOF2 (Aleutian Low index)

1976, 1978, 1983, 1986, 1989 and 1990 (Fig. 1). During 2 yr ENSOs (1972-73, 1982-83; Fig. 2), sea-surface temperature anomalies (as indicators of ENSO onset) were not positive off California until late the first year after most Farallon seabirds had completed breeding; thus, effects on reproduction of seabirds (as we measure it here) were not apparent in the first year. Frequent negative anomaly was most apparent in pelagic cormorant and pigeon guillemot, both of which dive deep but exhibit a restricted foraging range and diet under all conditions. The more trophically flexible western gull and Brandt's cormorant showed lessened variability.

Contrasting the years of negative reproductive anomalies were those of positive anomalies: 1971, 1975 , 1977, 1979, 1981, 1985 and 1987. Positive, like negative, anomalies were most evident among species that lay large clutches, particularly pelagic cormorant and pigeon guillemot. These 2 species, in fact, rarely experienced 'average' reproductive success. During years of greatest positive anomaly they did so well that reproductive success exceeded all respective values ever measured elsewhere in their subarctic range, as did chick growth rates (Ainley \& Boekelheide 1990).

The year-to-year reproductive success of several species exhibited a negative autocorrelation between years. The pattern was significant for the 2 species most sensitive to prey availability, pelagic cormorant and pigeon guillemot (Table 1). Thus, years of strong positive reproductive success were followed (or preceded) by negative success.

\section{Causes of productivity variation}

In multiple regressions using only independent variables that were each significant, 40 to $56 \%$ of variabil- 
Table 1 Autocorrelation (lag 1) indicating whether or not years of positive and negative anomaly alternated; reproductive success of Farallon seabird species, 1971 to 1991

\begin{tabular}{|lcc|}
\hline Species & Autocorrelation (lag 1) & Probability \\
\hline Brandt's cormorant & -0.02 & $>0.10$ \\
Pelagic cormorant & -0.53 & $<0.05$ \\
Western gull & 0.16 & $>0.10$ \\
Common murre & $<0.01$ & $>0.10$ \\
Pigeon guillemot & -0.36 & $<0.10$ \\
Cassin's auklet & 0.05 & 0.10 \\
& & \\
- Runs test, a 2-tailed test, considered significant at \\
alpha $<0.10$ in this exploratory analysis \\
\hline
\end{tabular}

ity in seabird reproductive success (depending on species) was explained by the physical factors retained in the model. Including all factors that maximized the amount of explained variation (maximum adjusted $\mathrm{r}^{2}$ ), 47 to $61 \%$ of variability in reproductive success was explained (Table 2). In both analyses, SO-Winter (plus at least 1 local variable) was the most consistent component of the various regression models (5 of 6 species). In the second analysis, AL-Summer also remained in the models ( 4 of 6 species). The Upwelling Index in January+February and sea-surface temperature in March were the most frequent local factors retained ( 5 of 6 species; Table 2). When only the EOFs were used in the regressions, SO-Winter was in all 6 models and AL-Summer was in 4 of 6 (Table 3). We used lagged variables $(-1)$ to test whether EOFs of the period preceding the seabird reproductive season affected results, but no significant relationships were apparent.

The physical values are only surrogates of prey availability. We related reproductive success directly to prey availability during the period when adult seabirds are provisioning their chicks at the nest (June-July). As detailed in the 'Introduction' and 'Methods', we used composition of the murre diet during June to index prey availability; no data were available for prey availability during other periods of the year. Prevalence of juvenile rockfish during the chickprovisioning period explained 27 to $67 \%$ of annual variation in reproductive success depending on seabird species (Fig. 3). Upwelling during January \& February and sea-surface temperature during March explained $73 \%$ of annual variation in the prevalence of rockfish [Table 4; findings also reported by Ainley et al. (1993) using a slightly shorter data set]. When retaining variables to maximize adjusted $r^{2}, 77 \%$ of variation was explainable. In this case, 3 EOF values were retained in the model.

Finally, we added prevalence of juvenile rockfish into the stepwise regression matrix that included all the physical variables. Prevalence of rockfish in the diet is explained by upwelling during January \& February (Ainley et al. 1993). By doing this, we thought that we might be able to determine the degree to which the physical variables could be surrogates of prey availability outside of the chick-provisioning period, when no prey data are available within the seabirds' foraging range. These final regression models greatly improved the ability to explain variation in

Table 2. Results of regression analyses showing physical variables comprising a model in which the adjusted $\mathrm{r}^{2}$ value is maximized to explain reproductive success, rs, in Farallon seabirds, 1971 to 1986 . Blank values were dropped from the model

\begin{tabular}{|c|c|c|c|c|c|c|c|}
\hline & SO-Sum & SO-Win & AL-Sum & AL-Win & $U W-J+F$ & T-MAR & SL-FEB \\
\hline \multicolumn{8}{|c|}{ Brandt's cormorant, rs; $C=-0.281$, maximum adj. $r^{2}=0.612$} \\
\hline$\beta$ & - & -0.182 & -1.749 & -0.505 & - & 0.140 & - \\
\hline $\mathrm{p}$ & - & 0.028 & $<0.001$ & 0.127 & - & 0.250 & - \\
\hline \multicolumn{8}{|c|}{ Pelagic cormorant, $\log (1+\mathrm{rs}) ; C=0.577$, maximum adj. $\mathrm{r}^{2}=0.509$} \\
\hline$\beta$ & - & -0.172 & -0.494 & - & -0.012 & - & -0.003 \\
\hline $\mathrm{p}$ & - & 0.012 & 0.134 & - & 0.155 & - & 0.017 \\
\hline \multicolumn{8}{|c|}{ Western gull, rs; $C=4.701$, maximum adj. $r^{2}=0.484$} \\
\hline$\beta$ & - & - & -0.329 & - & -0.009 & -0.277 & - \\
\hline $\mathrm{p}$ & - & - & 0.143 & - & 0.233 & 0.035 & - \\
\hline \multicolumn{8}{|c|}{ Common murre, rs; $C=3.697$, maximum adj. $r^{2}=0.603$} \\
\hline$\beta$ & -0.064 & 0.076 & - & -0.258 & -0.021 & -0.239 & -0.001 \\
\hline $\mathrm{p}$ & 0.027 & 0.092 & - & 0.150 & 0.015 & 0.035 & 0.291 \\
\hline \multicolumn{8}{|c|}{ Pigeon guillemot, $\log (1+\mathrm{rs}) ; C=0.006$, maximum adj. $\mathrm{r}^{2}=0.466$} \\
\hline$\beta$ & - & -0.032 & - & - & -0.032 & -0.002 & -1.813 \\
\hline $\mathrm{p}$ & - & 0.022 & - & - & 0.024 & 0.151 & $<0.003$ \\
\hline \multicolumn{8}{|c|}{ Cassin's auklet, rs; $C=35.968$, maximum adj. $r^{2}=0.554$} \\
\hline$\beta$ & - & 24.934 & -0.861 & 0.296 & 0.531 & -0.106 & - \\
\hline $\mathrm{p}$ & - & 0.114 & 0.021 & 0.127 & 0.163 & 0.010 & - \\
\hline
\end{tabular}


Table 3. Results of regression analyses showng only EOF variables comprising a model in which the adjusted $r^{2}$ value is maximized to explain reproductive success, rs, in Farallon seabirds, 1971 to 1986

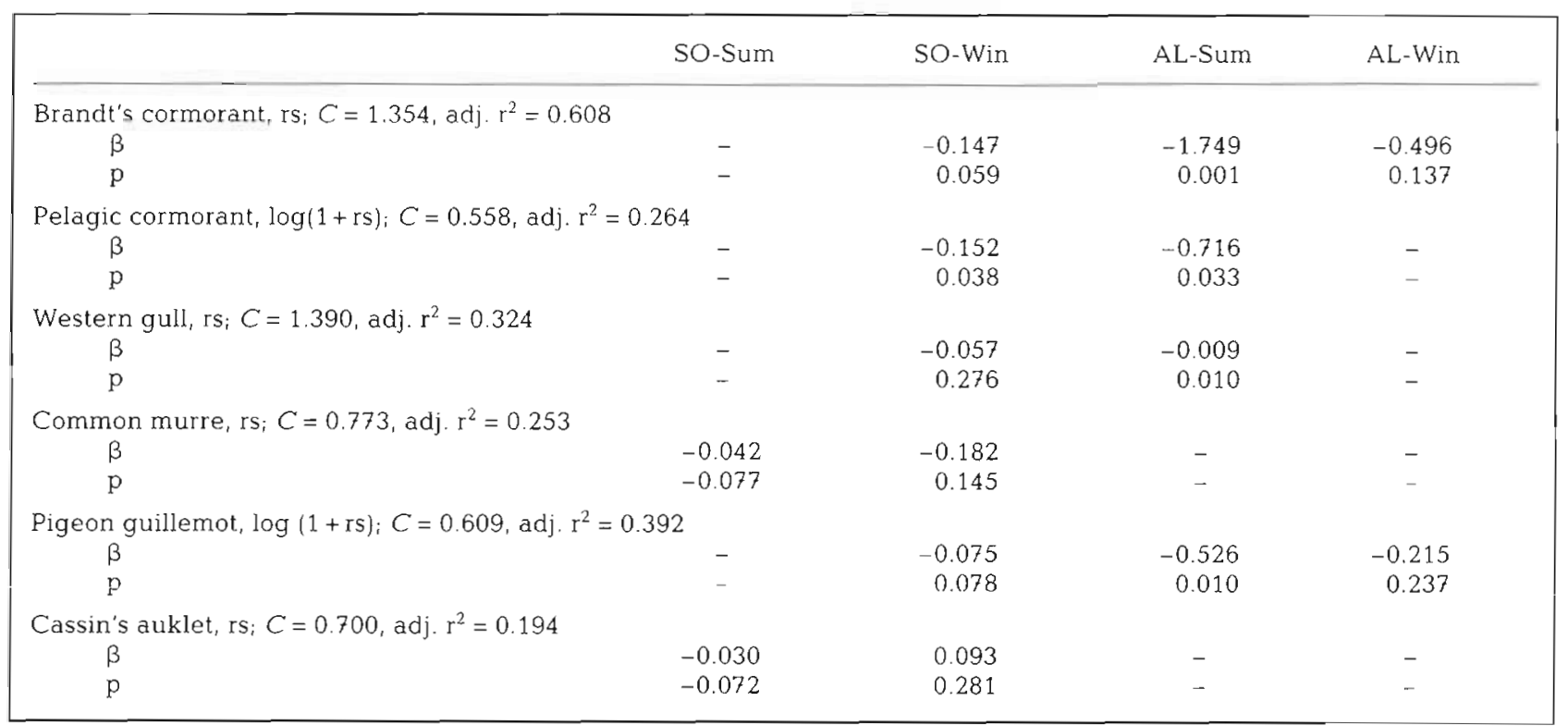

reproductive success for only 1 species, the pigeon guillemot (Table 5). The new model for this species explained $95 \%$ of annual variation in reproductive success (cf. Tables $3 \& 5$ )! Models for the other species were not or were only slightly affected by the addition of rockfish prevalence to the regression.

\section{DISCUSSION}

Variability in reproductive success of the California seabirds depend on the breeding and trophic plasticity of respective species (Ainley \& Boekelheide 1990). Pelagic and Brandt's cormorant, western gull and pigeon guillemot lay more than 1 egg per annual nesting attempt and, thus, when food is abundant can produce multiple young. Common murre and Cassin's auklet lay 1 egg and, in contrast, cannot respond to food surplus except by increased chick growth rates (Ainley \& Boekelheide 1990); i.e fatter chicks have a higher chance of subsequent survival. The murre and auklet, however, because of their more conservative breeding capacity appear better able to cope when food is not available. Their reproductive success, thus, varied little.

Our results show that much remains to be learned about perturbations in the upper portions of the food web of the California Current system. The variable 'AL-Summer' appears to be an important factor in affecting food availability to seabirds and is temporally consistent with the seabird breeding season in central California with respect to calendar months (March to August overlapping a nesting season of April to July). In addition, the mid-point of the 12 mo interval ending with spring-summer, i.e. January, is also consistent with the late-winter period that other studies have

Table 4. Results of regression analyses showing physical variables comprising a model in which the adjusted $r^{2}$ value is maximized to explain the percentage of juvenile rockfish in the diet of common murres on the Farallon Islands, 1973 to 1986

\begin{tabular}{|c|c|c|c|c|c|c|c|}
\hline & SO-Sum & SO-Win & AL-Sum & AL-Win & $U W-J+F$ & T-MAR & SL-FEB \\
\hline \multicolumn{8}{|c|}{ Significant variables only } \\
\hline \multicolumn{8}{|c|}{ Percent rockfish, $C=77.798$ adj. $\mathrm{r}^{2}=0.681$} \\
\hline$\beta$ & - & - & - & - & 1.245 & -0.504 & - \\
\hline $\mathrm{p}$ & - & - & - & - & $<0.001$ & 0.008 & - \\
\hline \multicolumn{8}{|c|}{$\begin{array}{l}\text { Variables maximizing adjusted } \mathbf{r}^{2} \\
\text { Percent rockfish, } C=63.154, \text { adj. } r^{2}=0.772\end{array}$} \\
\hline$\beta$ & - & 0.512 & 0.188 & -11.20 & 1.352 & -0.416 & - \\
\hline $\mathrm{p}$ & - & 0.105 & 0.188 & 0.143 & 0.001 & 0.022 & - \\
\hline
\end{tabular}



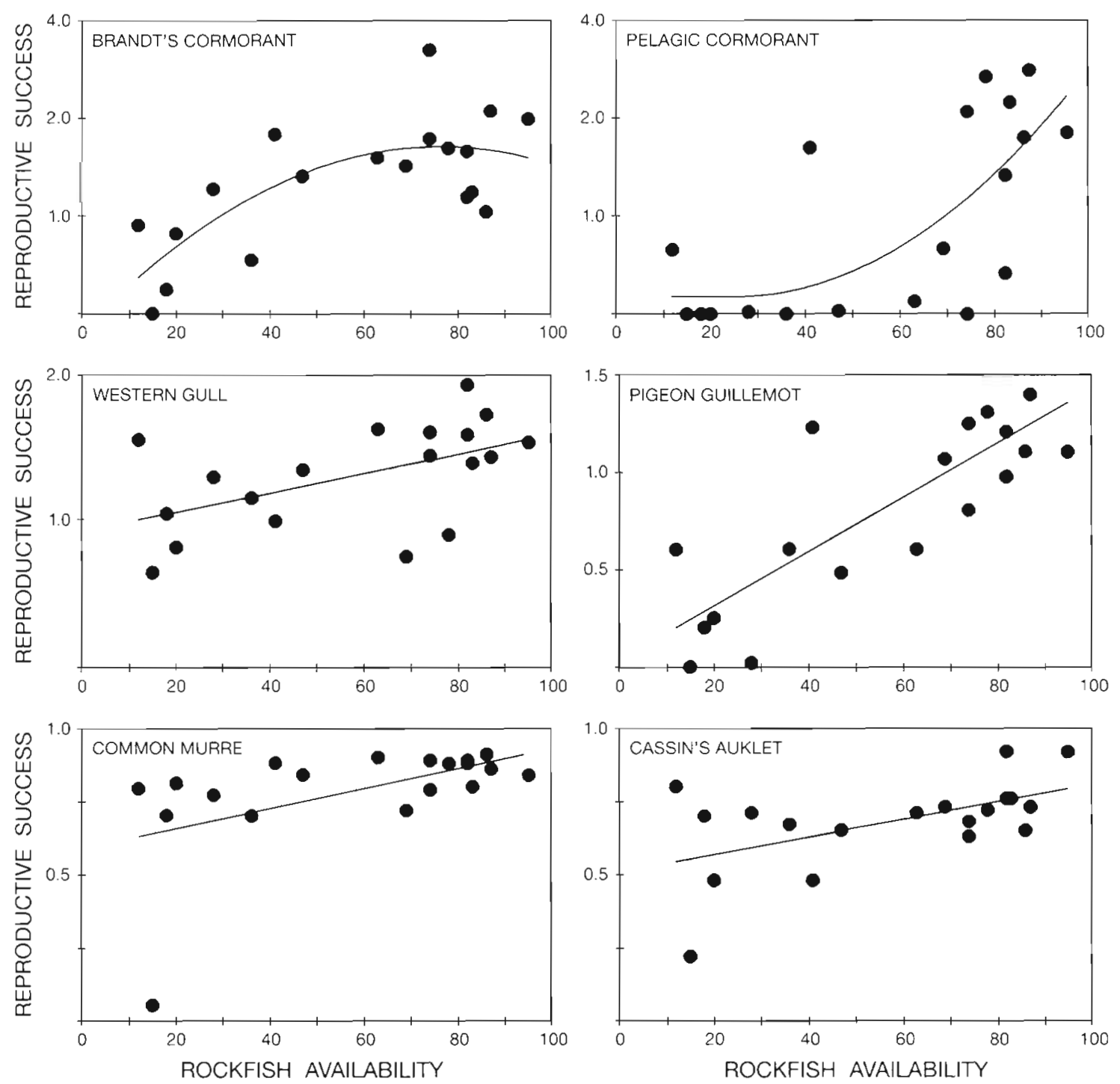

Fig. 3. Relationship, for 6 seabirds, between breeding productivity and rockfish availability, as determined by the proportion of rockfish in the murre diet. Equations of regression are as follows:

Brandt's cormorant: $y=-1.35+0.697 x^{2}, r^{2}=0.51, p=0.001$

Western gull: $y=0.917+0.007 x, \mathrm{r}^{2}=0.28, \mathrm{p}=0.020$

Common murre: $y=0.587+0.003 x, r^{2}=0.27, p=0.024$

shown to be critical to development of prey resources important to the birds' breeding efforts (e.g. Wylie Echeverria 1987, Ainley et al. 1993).

Seemingly problematic is the even greater importance of SO-Winter, a factor that represents the fallwinter period (September to February) after the sea bird reproductive season. September to February, of course, is the period when maximum effect of ENSO is usually apparent. Changes are underway, however, well before; the period of maximum response can be attained 3 to 9 mo after a perturbation in the Southern Oscillation (Norton \& McLain 1994). Indeed, oceanic processes that culminate in the fall-winter conditions
Pelagic cormorant: $y=0.033+0.0002 \mathrm{x}^{2}, \mathrm{r}^{2}=0.48, \mathrm{p}=0.001$

Pigeon guillemot: $y=0.035+0.014 x, r^{2}=0.67, p=0.001$

Cassin's auklet: $y=0.507+0.003 x, r^{2}=0.30, p=0.016$

begin to perturb the California Current environment early in ENSO events and within 1 mo of effects apparent along the Equator (Huyer \& Smith 1985, Rienecker \& Mooers 1986). Moreover, the EOF values in the study of Norton \& McLain represent the integration of processes over the year interval that leads to the state measured in the nominate, e.g. fall-winter, period (see their Fig. 11). Thus, considering the short versus long time lags (between perturbation and maximum effect), respectively, of $\mathrm{SO}$ and $\mathrm{AL}$, these are much more contemporaneous than our temporal designation at first indicates. In concert, the seabirds are also indicating that significant food web perturbations are under way 
Table 5. Results of regression andysus showing physical variables, plus prevalence of juvenile rockfish in the seabird diet, comprisıng a model in which the adjusted $r^{2}$ value is maximized to explain reproductive success, rs, in Farallon seabirds, 1971 to 1986

\begin{tabular}{|c|c|c|c|c|c|c|c|c|}
\hline & SO-Sum & SO-Win & AL-Sum & A.L-Win & UW-J+F & T-MAR & SL-FEB & DIET \\
\hline \multicolumn{9}{|c|}{ Brandt's cormorant, rs; $C=-2.761$ adj. $r^{2}=0.639$} \\
\hline$\beta$ & - & -0.306 & -1.868 & - & - & 0.345 & -0.002 & - \\
\hline $\mathrm{p}$ & - & 0.010 & 0.002 & - & - & 0.089 & 0.162 & - \\
\hline \multicolumn{9}{|c|}{ Pelagic cormorant, $\log (1+\mathrm{rs}) ; C=0.047$, adj. $\mathrm{r}^{2}=0.562$} \\
\hline$\beta$ & - & -0.172 & - & 0.301 & - & - & -0.002 & 0.008 \\
\hline $\mathrm{p}$ & - & 0.032 & - & 0.338 & - & - & 0.107 & 0.114 \\
\hline \multicolumn{9}{|c|}{ Western gull, rs; $C=5.266$, adj. $r^{2}=0.508$} \\
\hline$\beta$ & - & - & -0.448 & - & -0.018 & -0.323 & - & - \\
\hline $\mathrm{p}$ & - & - & 0.076 & - & 0.075 & 0.022 & - & - \\
\hline \multicolumn{9}{|c|}{ Common murre, rs; $C=3.700$, adj. $r^{2}=0.603$} \\
\hline$\beta$ & -0.064 & 0.076 & - & -0.258 & -0.022 & -0.239 & -0.001 & - \\
\hline $\mathrm{p}$ & 0.027 & 0.092 & - & 0.150 & 0.015 & 0.035 & 0.291 & - \\
\hline \multicolumn{9}{|c|}{ Pigeon guillemot, $\log (1+\mathrm{rs}) ; C=1.277$, adj. $r^{2}=0.921$} \\
\hline$\beta$ & - & -0.059 & - & - & -0.004 & -0.087 & -0.001 & 0.006 \\
\hline $\mathrm{p}$ & - & 0.006 & - & - & 0.286 & 0.068 & 0.034 & 0.001 \\
\hline \multicolumn{9}{|c|}{ Cassin's auklet, $\mathrm{rs}_{i} C=0.712$ adj. $\mathrm{r}^{2}=0.659$} \\
\hline$\beta$ & -0.047 & - & 0.184 & - & -0.008 & - & -0.004 & - \\
\hline $\mathrm{p}$ & 0.008 & - & 0.040 & - & 0.018 & - & 0.002 & - \\
\hline
\end{tabular}

long before maximum anomalies in physical conditions are evident. The fact that we found no significant correlations between reproductive success and $\mathrm{SO}$ of the previous year (i.e. the fall-winter preceding the reproductive season) is further support for our supposition.

It is possible that if Norton \& McLain (1994) had temporally partitioned their results into smaller periods (rather than just 2), our analysis and theirs would have matched even more closely. Also, if their analysis had been directed just at central California, the effect of spatial averaging whose geographic center is well to the north (i.e. Oregon) would have also provided a greater temporal match. It is well known that ocean seasons (e.g. peak of maximum upwelling; Bakun 1973) and effects of ENSO (McLain et al. 1985) progress northward along the coast in the eastern North Pacific. Correspondingly, the initiation of seabird reproduction in Oregon is a month or more later than in central California depending on species (cf. Scott 1973, Ainley \& Boekelheide 1990). Thus, geographic position has much bearing on the temporal aspects of both ocean perturbation and avian reproduction.

Results show the validity of the partitioning of ocean warming events off California by Norton \& McLain (1994) into EOFs related to the Southern Oscillation and the Aleutian low pressure system, at least from a biological perspective. With just EOFs in the regression matrix, the one representing $\mathrm{SO}$ conditions, i.e. SO-Winter, and that representing AL conditions, ALSummer, were retained in the models for most avian species. This is consistent with the time lags, noted by
Norton \& McLain (1994), whereby perturbations in respective distant areas propagate signals to affect the California Current, the response to perturbations in the $\mathrm{AL}$ (EOF2s) being much more immediate than those of the SO. Only 2 models, those for common murre and Cassin's auklet, retained SO-Summer. These are the 2 seabird species that feed heavily on euphausiids, particularly Thysanoessa spinifera and Euphausia pacifica (Ainley \& Boekelheide 1990, PRBO unpubl. data). These organisms (especially E. pacifica) occur deep in the water column (S. Smith pers. comm.) and, thus, potentially are more directly sensitive than are other prey species to deep changes in thermal structure brought by Kelvin waves (which affect thermocline depth). These euphausiids are particularly important for these seabirds during the pre-breeding period in late winter before the rockfish become available (PRBO unpubl. data).

The fact that EOF2s (mostly AL-Summer) fell out of the regression models when local factors, such as upwelling index, sea-surface temperature and sea level, were added is also consistent with the interpretation of Norton \& McLain (1994). The strength and position of the Aleutian low pressure system has direct bearing on the strength of upwelling-favorable winds in the Califormia Current. A relaxation or intensification of these winds allows offshore warm waters to move shoreward or be displaced seaward by upwelled water, respectively (e.g. Bolin \& Abbott 1963, Hickey 1979). The relaxation of winds also brings a rise in sea level as the offshore waters move coastward (Chelton 1981). In their analysis, Norton \& McLain considered EOF2s to 
represent local conditions relative to the very remote forcing by the $\mathrm{SO}$ (EOF1s); for our purposes, relative to real-time, immediate conditions, we considered both the $\mathrm{AL}$ and $\mathrm{SO}$ to be 'remote' (or, one could consider AL to designate 'regional' conditions). Thus, AL-Summer appears to be a valid surrogate of the truly immediate, local conditions that affect the spring-summer breeding season of the seabirds. Ainley et al. (1993) found that advection by strong, persistent winds strongly affects the availability of rockfish juveniles in the vicinity of the Farallones. Those results, too, are consistent with the surrogate value of AL-Summer.

The fact that actual prey availability during the chick provisioning period did not significantly improve the explanation of variability in reproductive success for most species also added credence to use of the surrogate physical EOF values. The improved explanation on the part of the pigeon guillemot, however, was dramatic. For that species, more than any of the others, whether or not they breed at all must have little to do with the local factors in the California Current near the Farallones and preceding the time of egg-laying and parenting. In fact, of the 6 species studied, the guillemot is the only one that does not reside year-round in the vicinity of the Farallones. Indeed, except when breeding, the species occurs in British Columbia north of the California Current. These results increase our confidence still more that the EOFs help to explain food-web variability especially during the time of year when no prey data are available.

Two aspects of the results deserve further comment. First, negative reproductive anomalies occurred during each El Niño (1973, 1976, 1983 and 1986) but classic El Niño conditions do not explain all negative perturbations in the productivity of eastern boundary current systems (see also Bernal 1981, Chelton 1981, McLain \& Thomas 1983, Norton et al. 1985). From the perspective of Farallon seabirds, reduced population size and breeding failure, i.e expected consequences of the perturbed food web brought by El Niño (Barber \& Chavez 1984, 1986), occurred also in 1978, 1989 and 1990, none of which was an official El Niño year (see Pares-Sierra \& O'Brien 1989, Johnson \& O'Brien 1990a, b, Philander 1990).

Other researchers have noted unusual aspects of the ocean off California during 1978 (Brinton 1981, Chelton et al. 1982, McLain et al. 1985). Although changes in the Aleutian low pressure system were involved in affecting California oceanography in 1978 (Norton et al. 1985, Norton \& McLain 1994, this study), perturbations were also noted around the globe: a negative anomaly clearly stood out in South African oceanographic, fisheries and seabird data (Duffy et al. 1984, Shannon et al. 1984, McLain et al. 1985), as did poor reproductive success of seabirds in the Scotia Sea
(Croxall et al. 1988) and in the eastern Canadian Arctic (Birkhead 1993). In the last case, reproductive failure was caused by pack ice that did not disappear during summer, as it does usually; see also Niebauer \& Day (1989) for anomalous ice conditions in the opposite extreme during 1978-79 in the Bering Sea and not related to ENSO. Other aspects of the unusual meteorological conditions between 1976 and 1978 have been discussed (Rasmusson et al. 1984, Emery \& Hamilton 1985, Kerr 1985), and years similar to 1978 have been noted with respect to the eastern North Pacific (Norton et al. 1985, Norton \& McLain 1994). The implication is that a large-scale ocean-atmosphere perturbation occurs periodically, with results in eastern boundary currents and elsewhere that can be as equally severe biologically (and physically, i.e. warm water) as those brought by ENSO.

Second, positive anomalies were just as spectacular and appear to be just as worthy of investigation as are negative ones. As a result of events in 1982-83, the marine biological literature is now replete with reports mainly of negative excursions from normality related to El Niño. Yet infrequent, positive reproductive anomalies and recruitment, for instance, can sustain fisheries on long-lived fish species for decades (e.g. Sissenwine 1984, MacCall 1986, Norton 1987) just as the infrequent strong year-classes of apex predators can also maintain their respective populations (e.g. Ainley et al. 1990). In the present study, 7 of the 21 years when many seabird species produced few young were countered by 7 when they were extremely productive. The years of negative anomaly were all preceded (or followed) by those when seabirds were exceptionally successful. Results were significant for the 2 species most sensitive to food web perturbation owing to their inability to forage over wide areas: pelagic cormorant and pigeon guillemot. Boersma (1978), in a singlespecies and shorter-term analysis than the present one, also noted exceptional productivity in Galápagos penguins Spheniscus mendiculus during the year preceding El Niño 1972-73. Thus, determining the conditions that lead to these positive annual anomalies should be just as important as the negative ones. Taken together, we should be able to learn most about the system by studying the opposite extremes (e.g. Chelton et al. 1982). Whether or not the positive anomalies are related to the reversal or opposite of El Niño in the ENSO cycle remains to be determined. Indeed, some of these positive years $(1971,1987)$ are now recognized as 'La Niña' (Kerr 1988, Philander 1990, Norton \& McLain 1994).

In conclusion, the present study confirms that El Niño (i.e. the warming aspect of ENSO) is not the only factor that can significantly perturb the ocean and food web in the eastern North Pacific, and that atmospheric 
teleconnections between various parts of the globe - a most difficult area of research - likely play a strong role in affecting significant perturbation in the food webs of eastern boundary current systems (see also Pares-Sierra \& O'Brien 1989, Johnson \& O'Brien 1990a, b, Philander 1990). At present, no programs exist that sample sufficiently in time and space to answer details of how food web interactions and structure are affected in the upper and middle trophic levels of these systems. Our motivation here in statistically comparing the top predators and potential physical forcing mechanisms was to invoke interest in further exploration of the causes of variability in the food web structure of the California Current system, particularly in its middle and upper levels.

Acknowledgements. We thank the U.S. Fish and Wildlife Service, Farallon National Wildlife Refuge (USFWS) for cooperatıon. The Oceanic Soclety (Farailon Patrol), many volunteers and other PRBO staff contributed mightily. G. Mitchum of NOAA-TOGA and D. Husby of NOAA-NMFS-PFEG contributed ocean data. Helpful comments on the manuscript were supplied by D. Boersma, K. Briggs, C. Ribic, G. Sharp, N. Nur ana 3 anonymous reviewers. Collection of seabird data was funded by USFWS and PRBO; analysis was funded by NSF grant OCE 8911125. This is contribution no. 298 of $\mathrm{PRBO}$.

\section{LITERATURE CITED}

Ainley, D. G., Boekelheide, R. J. (eds.) (1990). Seabirds of the Farallon Islands. Stanford University Press, Palo Alto

Ainley, D.G., Ribic, C. A., Wood, R. C. (1990). A demographic study of the South Polar Skua Catharacta maccormicki at Cape Crozier. J. Anim. Ecol. 59: 1-20

Ainley, D. G., Sydeman, W. J., Parrish, R. H., Lenarz, W H (1993). Oceanic factors influencing occurrence patterns of young rockfish (Sebastes) in central California: a predator's perspective. Calif. Coop. Ocean. Fish. Invest. Rep. 34 $133-139$

Bakun, A. (1973). Coastal upwelling indices, West Coast of North America, $1946-71$ U.S. Dept Commerce, NOAA Tech. Rep. NMFS SSRF-671

Barber, R. T., Chavez, F. G. (1984). Biological consequences of El Niño. Science 222: 1203-1210

Barber, R. T., Chavez, F. G. (1986). Ocean variability in relation to living resources during the 1982-83 El Niño. Nature 319: 279-285

Bernal, P. A. (1981). A review of low-frequency response of the pelagic ecosystem in the California Current. Calif. Coop. Ocean. Fish. Invest Rep. 22: 49-62

Birkhead, T R. (1993). Great Auk Islands. T \& A. D. Poyser, London

Boersma, P. D. (1978). Breeding patterns of Galápagos Penguins as an indicator of oceanographic conditions. Science 200: 1481-1483

Bolin, R. L., Abbott. D. P. (1963). Studies on the marine climate and phytoplankton of the central coastal area of California, 1954-60. Calif. Coop. Ocean. Fish. Invest. Rep. 9: $23-45$

Burton, E. (1981). Euphausiid distroutions in the California Current during the warm-water spring of $1977-78$, in the context of a 1949-66 time series. Calif. Coop. Ocean. Fish. Invest. Rep. 22: 135-154

Cheltom, D. B. (1981). Interannual variabulity in the California Current - physical factors. Calif. Coop. Ocean. Fish. Invest. Rep. 22: $34-48$

Chelton, D. B., Bernal, P. A., McGowan, J. A. (1982). Largescale interannual physical and biological interaction in the California Current. J. mar. Res. 40; 1095-1125

Croxall, J. P., McCann, T S., Prince, P. A., Rothery, P. (1988). Reproductive performance of seabirds and seals at South Georgia and Signy Island, South Orkney Islands, 1976-1987. In: Sahrhage, D. (ed.) Antarctic Ocean and resources variability. Springer-Verlag, Berlin, p. 261-285

Duffy, D.C., Berruti, A., Randall, R. M., Cooper, J. (1984). Effects of the 1982-3 warm water event on the breeding of South African seabirds. S. Afr. J. Sci. 80: 65-69

Emery, W. J., Hamilton, K. (1985). Atmospheric forcing of interannual variability in the northeast Pacific Ocean: connections with El Niño. J. geophys. Res. 90(C1): 857-868

Glantz, M. H., Thompson, J. D. (eds.) (1981). Resource management and environmental uncertainty. John Wiley \& Sons, New York

Hickey, B. M. (1979). The California Current systemhypothesis and facts. Prog. Oceanogr. 8: 191-279

Huyer, A., Smith, R. L. (1985). The signature of El Niño of Oregon, 1982-1983. J. geophys. Res. 90(C4): 7133-7142

Iohnson, M. A., O'Brien, J. J (1990a). The northeast Pacific Ocean response to the 1982-83 El Niño. J. geophys. Res. 95(C5): $7155-7166$

Johnson, M. A., O'Brien, J J. (1990b). The role of coastal Kelvin waves on the northeast Pacific Ocean. J. mar. Syst. 1. $29-38$

Kerr, R. A. (1985). Wild string of winters confirmed. Science 227: 506

Kerr, R. A. (1988). La Niña's big chill replaces El Niño. Science 241: $1037-1038$

MacCall, A. (1986). Changes in the biomass of the California Current ecosystem. In: Sherman, K., Alexander, L. M. (eds.) Variability and management of large marine ecosystems. Am. Ass. Adv. Sci., Washington, DC, p. 33-54

Mclain, D. R., Brainard, R. E., Norton, J. G. (1985). Anomalous warm events in eastern boundary current systems. Calif. Coop. Ocean. Fish. Invest. Rep. 26: 51-64

McLain, D. R., Thomas, D. H. (1983). Year-to-year fluctuations of the California Countercurrent and effects on marine organisms. Calif. Coop. Ocean. Fish. Invest. Rep. 24: $165-180$

Montevecchi, W. A. (1993). Birds as indicators of change in marine prey stocks. In: Furness, R. W., Greenwood, J, J. D. (eds.) Birds as monitors of environmental change. Chapman and Hall, London, p. 217-266

Murphy, R. C. (1981). The guano and anchoveta fishery. In: Glantz, M. H., Thompson, J. D. (eds.) Resource management and environmental uncertainty. John Wiley and Sons, New York, p. 81-106

Niebauer, H. J, Day, R. H. (1989). Causes of interannual variability in the sea ice cover of the eastern Bering Sea. CieoJournal 18.1: 45-59

Norton, J. (1987). Ocean climate influences on groundfish recruitment in the California Current. In: Proc. Int. Rockfish Symp. Univ. Alaska Sea Grant, Fairbanks, p. 73-98

Norton, J., Cayan, D. R., McLain, D. R. (1994). Near and distant connection of atmospheric systems to ocean temperature change in the coastal California Current region. In: Redmond, K. T., Sharp, V. L. (eds.) Proc. Tenth Annual Pacific Climate (PACLIM) Workshop, California Department of Water Resources, Interagency Ecological Studies 
Program, Technical Report 36: 93-105

Norton, J., McLain, D. (1994). Diagnostic patterns of seasonal and interannual temperature variation of the west coast of the United States: local and remote large scale atmospheric forcing. J. geophys. Res. 99(C8): 16019-16030

Norton, J., McLain, D., Brainard, R., Husby, D. (1985). The 1982-83 Niño event off Baja and Alta California and its ocean climate context. In: Wooster, W. S., Fluharty, D. L. (eds.) El Niño North: Niño effects in the eastern subarctic Pacific Ocean. Washington Sea Grant, University of Washington, Seattle, p. 44-72

Nur, N., Ford, R. G., Ainley, D. G. (1993). Computer model of Farallon seabird populations. Final Report Contract CX8140-1-0019, National Oceanic and Atmospheric Administration, Gulf of the Farallones National Marine Sanctuary, San Francisco

Pares-Sierra, A., O'Brien, J. J. (1989). The seasonal and interannual variability of the California Current system: a numerical model. J. geophys. Res. 94(C3): 3159-3180

Parrish, R. H., Nelson, C. S., Bakun, A. (1981). Transport mechanisms and reproductive success of fishes in the California Current. Biol. Oceanogr. 1: 175-203

Paulik, G. J. (1981). Anchovies, birds and fishermen in the Peru Current. In: Glantz, M. H., Thompson, J. D. (eds.) (1981). Resource management and environmental uncertainty. John Wiley and Sons, New York, p. 35-79

Pearcy, W. G., Schoener, A. (1987). Changes in the marine biota coincident with the 1982-83 El Niño in the northeastern subarctic Pacific Ocean. J. geophys. Res. 92(C13): $14417-14428$

Peterman, R. M., Bradford, M. J. (1987). Wind speed and mortality rate of marine fish, the northern anchovy (Engraulis mordax). Science 235: 354-356

This article was submitted to the editor
Philander, S. G. (1990). El Niño, La Niña, and the Southern Oscillation. Academic Press, New York

Priestly, M. B. (1981). Spectral analysis and time series. Academic Press, New York

Rasmusson, E. M., Reynolds, R. W., Arkin, P. A. (1984) 1982-83 ENSO episode revisited. Trop. Ocean-Atmosph. Newslett. 28: 5-6

Rienecker, M. M., Mooers, C. N. K. (1986). The 1982-1983 El Niño signal off northern California. J geophys. Res 91(C5): $6597-6608$

Robinson, G., del Piño, E. M. (eds.) (1985). El Niño in the Galapagos Islands: the 1982-1983 event. Charles Darwin Foundation, Quito

Scott, J. M. (1973). Resource allocation in four syntopic species of marine diving birds. Ph.D. dissertation, Oregon State University, Corvallis

Seber, G. A. F. (1977). Linear regression analysis. John Wiley \& Sons, New York

Shannon, L. V., Crawford, R. J. M., Duffy, D. C. (1984). Pelagic fisheries and warm events: a comparative study. S. Afr. J. Sci. 80: 51-60

Siegel, S. (1956). Nonparametric statistics for the behavioral sciences. McGraw-Hill Book Co., New York

Sissenwine, M. P. (1984). Why do fish populations vary? In: May, R. M. (ed.) Exploitation of marine communities. Springer-Verlag, Berlin, p. 59-94

Sydeman, W. J., Penniman, J. F., Penniman, T M., Pyle, P. Ainley, D. G. (1991). Breeding performance in the Western Gull: effects of parental age, timing of breeding and year in relation to food availability. J. Anim. Ecol. 60: 135-149

Wylie Echeverria, T. (1987). Thirty-four species of California rockfishes: maturity and seasonality of reproduction. Fish. Bull. U.S. 85: 229-250

Manuscript first received: March 8, 1994

Revised version accepted: December 7, 1994 